Published in final edited form as:

Circ Res. 2015 September 11; 117(7): e58-e63. doi:10.1161/CIRCRESAHA.115.305765.

\title{
Recent Developments in Heart Failure
}

\author{
Sujith Dassanayaka and Steven P. Jones \\ Institute of Molecular Cardiology, Diabetes and Obesity Center, Division of Cardiovascular \\ Medicine, Department of Medicine, and, Department of Physiology and Biophysics, University of \\ Louisville, Louisville, KY
}

Despite significant advances in cardiovascular medicine during the late $20^{\text {th }}$ century, heart failure (HF) remains a leading cause of death in the United States and much of the rest of the world ${ }^{1}$. Although improvements in acute management of cardiovascular disease have reduced death rates, efforts to halt the inexorable deterioration are largely futile. The current clinical approach focuses on disease management rather than curing heart failure - because there is presently no cure ${ }^{2}$. Primary treatment consists of angiotensin-converting enzyme inhibitors, beta-blockers, and mineralocorticoids antagonists. And, although a new class of agents (i.e. neprilysin inhibitor) has shown promise in a Phase 3 clinical trial ${ }^{3}$, collectively, these drugs only delay disease progression and death due to heart failure. Given the general stagnation in the progress of clinical treatment of heart failure, we must undertake more daring and high-risk preclinical studies to achieve the collective dream of curing heart failure. This "Developments" will highlight some recent progress in understanding the pathobiology of heart failure and advances in conceptual approaches for future treatments. The goal is to focus the readers' attention on some of the more exciting and daring areas of cardiovascular research, which will likely dictate advances in the $21^{\text {st }}$ century.

The central element of heart failure relates to the heart's inability to pump sufficient blood to meet the metabolic demands of the body. Although various factors can contribute to such a defect, myocardial infarction is the most frequent cause of heart failure. Following an infarction, the significant loss of cardiomyocytes is replaced with akinetic scar tissue, rather than contracting cardiomyocytes. Such 'wound healing' satisfies the short-term goal of retaining ventricular integrity; however, the chronic implications include progressive fibrosis, stiffness, and dilation of the ventricle. Thus, improving mechanical performance and limiting remodeling represent two key areas to address in the failing heart.

\section{Defects in lon Handling}

The basic contractile function of the heart is centrally regulated by ion exchange; in particular, the entry and exit of sodium and calcium, and propagation of action potentials. Although one could argue that elevated calcium during heart failure could augment cardiac function ${ }^{4}$, elevated $\mathrm{Ca}^{2+}$ can be detrimental and can lead to the development of arrhythmias, hypertrophy, and apoptosis ${ }^{5,6}$. More detailed discussion of calcium handling during heart failure can be found in a recent review ${ }^{7}$. Of course, $\mathrm{Na}^{+} / \mathrm{K}^{+}$ATPase, the primary ionic

Address for Correspondence: Steven P. Jones, PhD (Steven.P.Jones@ Louisville.edu), University of Louisville, 580 South Preston Street, Delia Baxter Building, Room 321F, Louisville, KY 40202, USA. 
regulator in cardiomyocytes, has a long history as a target in heart failure (remember cardiac glycosides?). The familiar $\mathrm{Na}^{+} / \mathrm{K}^{+}$ATPase has two subunits (a1, a2), which can couple with a sodium-calcium exchanger (NCX1) in T-tubules. Moreover, inhibition of the a 2 isoform can increase calcium transients indicating a possible link between $\mathrm{Na}^{+} / \mathrm{K}^{+}$ATPase a 2 and NCX1. Correll et al. recently examined the contribution of $\mathrm{Na}^{+} / \mathrm{K}^{+}$ATPase $a 2$ in regulation of disease progression ${ }^{8}$.

Indeed, calcium handling plays a central role in the failing heart, and the ryanodine receptor has long been the focus of heart failure studies. Calcium leak through ryanodine receptors (RyR2) contributes to atrial fibrillation ${ }^{9}$, and abnormal termination of $\mathrm{Ca}^{2+}$ release is a common defect of RyR2 mutations associated with - albeit rarely - cardiomyopathies ${ }^{10}$. Interestingly, CaMKII activity increases in HF and regulates RyR2 through phosphorylation of residue S2814 ${ }^{11}$, and CaMKII phosphorylation of RyR2 is sufficient to increase sarcoplasmic reticulum (SR) $\mathrm{Ca}^{2+}$ leak in mice and to contribute to cardiomyopathy. And, although there has been some disagreement ${ }^{12}$, hyperphosphorylation at a nearby site (S2808) does not appear to be a likely contributor to heart failure ${ }^{13}$.

\section{Inflammation and Remodeling}

The induction of the inflammatory response is a critical step in mediating cardiac repair following MI. Robust infiltration of leukocytes mediates removal of necrotic cardiomyocytes and initiates wound healing. Recruitment of these inflammatory cells results from release of chemoattractants from damaged and dying myocardium. These cells become recruited to both infarcted and non-infarcted areas. The inflammatory response also helps mediate extracellular matrix (ECM) synthesis through promoting fibroblast activation, ECM degradation, and altering matrix metalloproteinase (MMP) activity; however, chronic inflammation results in exacerbation of cardiomyocyte damage and cardiac dysfunction through adverse remodeling ${ }^{14}$. Thus, the regulation of the inflammatory response and its mediators may provide new therapeutic targets in HF.

Ischemic cardiomyocytes release ATP, which can serve as a chemoattractant to recruit phagocytes to sites of inflammation to clear dead cells and debris ${ }^{15}$. In addition, ATP can be released from neutrophils to guide other neutrophils to inflammatory sites. Extracellular ATP is rapidly dephosphorylated to ADP, AMP and adenosine. These resultant products may play an integral role in modulating immune cell infiltration and cardiac healing/ remodeling subsequent to I/R. Recent studies ${ }^{16}$ have identified CD39 as an ectonuclease responsible for the hydrolysis of ATP. Ecto-5'-nucleotidase (CD73) further hydrolyzes AMP to adenosine. Adenosine can subsequently induce both pro and anti-inflammatory responses. Immune cells in the unstressed heart exhibit marked levels of CD39 and lack CD73; however, $3 \mathrm{~d}$ after I/R invading leukocytes demonstrated significant upregulation of CD73.

Post-MI matrix metalloproteinase (MMP) activity increases in response to a host of inflammatory cytokines ${ }^{17}$. Activation of MMPs leads to degradation of myocardial matrix and cardiac remodeling, and pharmacological inhibition of MMPs has demonstrated attenuation of LV dilatation ${ }^{18,19}$. In addition to MMPs, the heart also expresses tissue inhibitors of matrix metalloproteinases (TIMPs), whose expression is actually reduced after 
MI. Thus, our general understanding has held that a relative imbalance exists between MMPs and TIMPs. And, although recent insights derived from cardiac expression of TIMP-4 demonstrates clearly this idea ${ }^{20}$, not all MMPs mediate maladaptive remodeling. MMP-28 appears to be necessary for proadaptive remodeling ${ }^{17}$. MMP-28 is expressed in cardiomyocytes in normal conditions; however, following MI, macrophages become a prominent source of MMP- $28^{17}$. Loss of MMP-28 leads to adverse LV remodeling and dysfunction, which is accompanied by increased death and rates of ventricular rupture ${ }^{17}$. When the phenotype of the macrophages was examined, it appeared that both proinflammatory factors and M2 macrophage polarization were reduced with MMP-28 deletion. In addition, extracellular matrix deposition and cross-linking, and myofibroblast numbers, were all reduced in MMP-28 KO mice ${ }^{17}$.

Clearly, macrophages play an important role in post-infarct wound healing, in part, through transition from M1 to M2 phenotype to reduce inflammation and mediate fibrosis. The necessity of macrophages in wound healing is even more evident in the neonatal heart. Macrophages play a pivotal part in cardiac regeneration and neoangiogenesis following myocardial injury ${ }^{21}$. Thus, their utility in mediating cardiac remodeling in the adult heart should be further explored. To this end, several elegant studies were published addressing primarily the role of macrophages in heart failure, and secondarily other aspects of inflammation. Ismahil et $\mathrm{al}^{22}$ developed the novel hypothesis that post-MI alterations of splenic function contribute to LV remodeling. In their study, the found that splenectomy blocked post-infarct LV remodeling, while reconstitution of naïve mice with heart failurederived macrophages largely recapitulated LV remodeling. The origin of cardiac macrophages has been somewhat enigmatic; however, recent discoveries indicate that whereas homeostatic maintenance of cardiac macrophages occurs via proliferation of existing cardiac macrophages, bone marrow-derived monocytes contribute to post-infarct cardiac macrophages $^{23}$. Another question to be answered is what regulates the distribution Ly-6C high (inflammatory) and Ly-6 $\mathrm{C}^{\text {low }}$ (reparative) monocytes? A study from Hilgendorf and colleagues ${ }^{24}$ addressed this important issue and found that $\mathrm{Nr} 4 \mathrm{a} 1$ (nuclear receptor subfamily 4) expression was associated with suppression of inflammation, and deletion of $\mathrm{Nr} 4 \mathrm{a} 1$ promoted adverse cardiac remodeling. Of course, macrophages are not solo actors in post-infarct inflammation; T lymphocytes may also exert critical regulatory effects on cardiac inflammation. Ablation of $\mathrm{T}_{\text {reg }}$ cells before $\mathrm{MI}$ exacerbates inflammation, promotes M1 macrophage polarization, and depresses cardiac function in the failing heart ${ }^{25}$.

\section{Regulation of Cardiac Hypertrophy}

Following cardiac injury, compensatory mechanisms, such as cardiac hypertrophy, maintain cardiac function. Cardiac hypertrophy serves primarily as an adaptive response to increased workload; however, chronically, hypertrophy is associated with increased interstitial fibrosis, apoptosis, and eventually heart failure. Hypertrophic growth requires gene regulation at multiple levels: epigenetic, transcriptional, post-transcriptional, and translational regulation. Regulation of hypertrophy in HF, especially the induction of the fetal gene program, has been studied extensively; however, new regulators have been identified. 
For example, G-protein-coupled receptors that result in the activation of $\mathrm{Gq}$ and its downstream effects stimulate hypertrophy. Among these downstream effectors are histone deacetylases (HDACs), which normally suppress expression of hypertrophic genes. Class II HDACs, including HDAC4 and HDAC5, interact with key transcription factors that mediate hypertrophy including nuclear factor of activated T cells (NFAT) and myocyte enhancer factor-2 (MEF2), and inhibit their activity through histone deacetylation. Yet, hypertrophic stimuli can activate HDAC kinases, such as protein kinase D, CamKII, and the recently discovered G-protein-coupled receptor kinase 5 (GRK5), which results in the phosphorylation and cytoplasmic translocation of class II HDACs and removal of their inhibitory effect on hypertrophic transcription factors. GRK5 overexpression promotes NFAT-induced activation of hypertrophic gene transcription, whereas GRK5 deficiency limits NFAT activation during pressure overload ${ }^{26}$. Thus, limiting GRK5 expression may protect against maladaptive cardiac growth and HF development.

In addition to HDAC kinases, oxidation of specific serine residues of class II HDAC can also result in their cytoplasmic translocation. Sources of oxidation include reactive oxygen species (ROS) that naturally result from physiological and pathological processes. In particular, NADPH oxidases are major sources of superoxide formation. Recently, NADPH oxidase 4 (Nox4) has been shown to increase ROS in response to hypertrophic stimuli, resulting in cysteine oxidation and nuclear export of HDAC4, a class II HDAC ${ }^{27}$. Similarly, deletion of Nox4 attenuates HDAC4 oxidation and cardiac hypertrophy two weeks following pressure overload ${ }^{27}$. Clearly, HADACs play an important role in suppressing hypertrophy, and regulating their activity may regulate the transition to decompensated $\mathrm{HF}^{28}$.

Controlling the intensity and duration of hypertrophic signaling may provide therapeutic benefit in HF. Interestingly, the Sussman group may have found a novel target for the regulation of cardiac hypertrophy in Pin1. Pin1, a proline directed isomerase extensively studied in cancer where it regulates proliferation, cell survival, lineage commitment, and aging, now appears to orchestrate cardiac hypertrophy. Pin1 is upregulated after pressure overload $^{29}$, and loss of Pin1 limits cardiomyocyte hypertrophy through the inhibition of Akt and MEK activation. Pin1 overexpression preserves cardiac function after pressure overload, possibly through inhibition of MEK but not $\mathrm{Akt}^{29}$. Because attenuation of the hypertrophic response was attributed to both overexpression and loss of Pin1, Toko et al surmised that Pin1 operates within a restricted range. Thus, Pin1 appears to facilitate an appropriate hypertrophic response through regulation of intensity and duration of hypertrophic signaling 29,30 .

Preserving cardiac function is the ultimate goal, and technological advances in mechanical circulatory support have led to the development of left ventricular assist devices (LVAD). These devices serve as a last resort therapeutic option for patients with end-stage heart failure to provide a bridge to transplantation. Considering the universal shortage of donor organs, LVADs offer decreased mortality and morbidity for those on a waiting list ${ }^{31}$. Following $30 \mathrm{~d}$ of LVAD implementation, patients exhibit recovery of ejection fraction ${ }^{32}$; however, such improvement often regresses to the pre-LVAD level upon withdrawal of $\mathrm{LVAD}^{32}$. As expected, cardiac tissue examined prior to and post-LVAD demonstrate 
reduced myocyte size and fibrosis without an obligatory improvement in function ${ }^{33}$. Such findings provide some limited promise for LVADs and re-emphasize the bidirectional nature of myocardial remodeling. Thus, understanding the underlying mechanisms may guide our ability to mend the failing heart.

\section{Gene/Molecular Therapy}

Because heart failure is not a single loss-of-function genetic abnormality, fine-tuning gene expression may represent another feasible avenue via microRNAs (miRs). These small, noncoding RNAs are responsible for genetic regulation at the post-transcriptional level. MiRs can directly modulate cardiac transcription and indirectly regulate other miRs. Thousands of miRs have already been identified and many regulate cardiac development ${ }^{34}$, pathological remodeling ${ }^{35}$, and cardiomyocyte hypertorphy ${ }^{36}$. One such regulator of hypertrophy, miR-22, mediates a compensatory hypertrophic response following pressure overload, and loss of miR-22 accelerates the progression of dilated cardiomyopathy ${ }^{37}$. Likewise, miR-24 expression increases during hypertrophy, and it is suppresses both junctophilin-2 (JP2) expression and attenuates excitation-contraction coupling ${ }^{38}$. In vivo treatment with antagomir against miR-24 preserved excitation-contraction coupling and prevented transition to decompensation ${ }^{38}$. Likewise, miR-25, which is a potent inhibitor of SERCA2a, can be blocked (via antagomiR) to improve contractility during $\mathrm{HF}^{39}, 40$.

Multiple additional effects of miRs have also been identified in HF. Not only can miRs direct cardiomyocyte remodeling, they can also affect resident fibroblasts. Interestingly, circulating miRs appear may be potential biomarkers of cardiovascular disease ${ }^{41}$, and, miR-1, miR-133a, and miR-208a are present in serum following myocardial infarction ${ }^{42,43}$. Matsumoto et al. found several, p53-responsive miRs (miR-192, miR-194, miR-34a) are upregulated after acute MI and may contribute to the development of $\mathrm{HF}^{41}$. These markers, however, have short half-lives and do not predict future HF after acute myocardial infarction. Of course, there are cautionary notes with miRs as therapeutic targets, as pointed out by Matkovich et $a l^{44}$.

Although once heralded as a definitive treatment for monogenic disorders, gene therapy has been slow to gain traction in cardiovascular medicine; however, several groups have recently reinvigorated interest in gene therapy to mitigate HF. Defective calcium handling is a key aspect of heart failure. Of the multiple regulators of calcium handling in heart failure, SERCA2 has received significant attention because of its primary role in calcium re-uptake to the sarcoplasmic reticulum. Indeed, SERCA2's activity is diminished in the failing heart ${ }^{45}$, and adenoviral administration of SERCA2a in failing cardiomyocytes improves contractility in various animal models of HF ${ }^{46-49}$. The resulting clinical trial, CUPID, demonstrated safety ${ }^{50}$ and efficacy ${ }^{51}$ of intracoronary infusion of recombinant AAV1/ SERCA2a. Through three years of follow up, gene therapy caused no adverse events, even though the SERCA2a transgene was present in patients up to 31 months post transfusion ${ }^{52}$. Gene therapy appears to be a feasible, clinical therapeutic option.

Ultimately, while preserving and enhancing cardiomyocyte function serves to potentiate the adverse effects of the failing heart, the need to address the loss of cardiomyocytes and their 
limited renewal still looms. Replacing the cardiomyocyte pool appears to be the limiting factor in mediating cardiovascular disease as most treatments are geared toward maintaining cardiomyocyte survival and function. Many are excited by the potential for cardiomyogenesis through gene transfer. Recent studies demonstrate the ability to reprogram cells into cardiomyocyte-like cells. It remains to be seen whether reprograming resident fibroblasts would provide clear clinical benefit. Subpopulations of resident cardiac fibroblasts do indeed have a cardiac-specific gene expression profile and may be primed for transdifferentiation ${ }^{53}$; however, cardiac fibroblasts, in general, do not contribute substantially to myocardial regeneration following injury ${ }^{53}$.

The key to genetic regulation of neocardiomyogenesis may revolve around regulation of the cardiomyocyte cell cycle to induce cardiomyocyte proliferation. Adult cardiomyocytes are terminally differentiated and have likely exited the cell cycle, diminishing any significant capacity for proliferation. Recently, Chen et al. studied the miR-17-92 cluster, a human oncogene that induces proliferation in the heart. Deletion of this cluster from embryonic and postnatal hearts reduced cardiomyocyte proliferation, and in vitro overexpression of the miR-17-19 cluster appears sufficient to induce cardiomyocyte proliferation ${ }^{54}$. Furthermore, overexpression of this cluster following MI modestly improved cardiac function, decreased scar formation, and induced cardiomyocyte proliferation ${ }^{54}$. Elucidating the molecular signaling mediated by this cluster may provide necessary molecular targets to mediate robust de novo cardiomyocyte formation in the context of cardiac necrosis. Additionally, at least one group has already overexpressed the Stem Cell Factor gene into infarcted myocardium ${ }^{55}$. Induction of SCF resulted in dramatic increase in progenitor cell recruitment to the myocardium. Combining recruitment of reparative cells and induction of cardiomyogenesis via gene therapy may prove to be a useful adjunct to induce cardiac regeneration ${ }^{56}$.

\section{Cell Therapy}

The heart was believed to be a post-mitotic organ with limited (if any) capacity for regeneration; however, discovery of putative stem/progenitor cells in the heart ushered in a relative renaissance in cardiovascular research. The most active - and certainly controversial $^{57-61}$ - area of investigation in cardiovascular research is cell therapy. Regardless of the origin and identity of the cells used, there is a general consensus that most cells "work" (i.e. improve cardiac function) - candidly, it seems a bit surprising that so many supposedly varied cell types can actually improve function. Nevertheless, the data indicate that cell therapy improves cardiac function in multiple animal models from multiple laboratories, as well as preliminary studies of patients.

Given the ever-increasing number of clinical trials completed, ongoing, and being planned to harness the promise of cell to repair the failing heart ${ }^{62}$, it is not surprising that the field continues to experience remarkable growth. Although several recently completed trials are varied in cell type and outcomes, they all exhibit limited adverse effects in patients indicating a suitable vehicle for further experimentation; that is, at minimum, cell therapy appears to be safe ${ }^{63-67}$. Currently, there is a race to find the most effective cell type to mediate cardiac regeneration and, eventually, improve clinical outcomes. The race to find 
the most therapeutic cell requires stringent and thorough examination of the regenerative potential and appropriate product control along the way. There are obstacles that still need to be surmounted, including developing high throughput methods for testing the cells. Purifying, selecting, and injecting potential cardiac progenitors to measure functional outcomes following HF without properly addressing the cells' functional and regenerative capacity is a timely and costly endeavor. In addition, there are a multitude of cell markers that may be attributable to therapeutic potential. Studying the efficacy of these cells in high throughput in vitro settings may be beneficial to the future of the field.

If, however, optimization of autologous cells does not prove successful, investigators may need to turn to allogeneic cell populations. It appears that immunogenic response to allogeneic stem cells may be modulated through programmed death ligand 1(PD-L1) ${ }^{68}$. Thus, cell populations that exhibit PD-L1 expression may serve as a selection criterion for allogeneic cardiac stem cells. Furthermore, mesenchymal precursor cells (MPCs) that are stromal precursor antigen $3+$ (Stro-3+), considered to be immune privileged, appear effective, safe, and feasible, and represent an allogeneic source of cells to treat acute $\mathrm{MI}$ in large animal models ${ }^{69}$.

This is an exciting time for the field of cell therapy. Although some of the cells may turn out to be unique subsets of fibroblasts, which many have speculated, they appear collectively to be effective in the hands of numerous investigators.

\section{Summary}

Advances in understanding cellular pathophysiology and elucidating mechanisms of selfrenewal lie at the crux alleviating HF. Establishing a panacea for HF is unlikely in the short term; however, a combination of adjunctive therapies, including pharmacological management, genetic regulation, and cell therapy may be the key to reinvigorating the failing heart.

\section{References}

1. Roger VL. Epidemiology of heart failure. Circulation research. 2013; 113:646-59. [PubMed: 23989710]

2. Braunwald E. Research advances in heart failure: a compendium. Circulation research. 2013; 113:633-45. [PubMed: 23888056]

3. McMurray JJ, Packer M, Desai AS, Gong J, Lefkowitz MP, Rizkala AR, Rouleau JL, Shi VC, Solomon SD, Swedberg K, Zile MR. Investigators P-H and Committees. Angiotensin-neprilysin inhibition versus enalapril in heart failure. The New England journal of medicine. 2014; 371:9931004. [PubMed: 25176015]

4. Despa S, Islam MA, Weber CR, Pogwizd SM, Bers DM. Intracellular Na(+) concentration is elevated in heart failure but $\mathrm{Na} / \mathrm{K}$ pump function is unchanged. Circulation. 2002; 105:2543-8. [PubMed: 12034663]

5. Pogwizd SM, Sipido KR, Verdonck F, Bers DM. Intracellular Na in animal models of hypertrophy and heart failure: contractile function and arrhythmogenesis. Cardiovascular research. 2003; 57:887-96. [PubMed: 12650867]

6. Bers DM, Despa S. Cardiac myocytes $\mathrm{Ca} 2+$ and $\mathrm{Na}+$ regulation in normal and failing hearts. Journal of pharmacological sciences. 2006; 100:315-22. [PubMed: 16552170] 
7. Luo M, Anderson ME. Mechanisms of altered $\mathrm{Ca}(2)(+)$ handling in heart failure. Circulation research. 2013; 113:690-708. [PubMed: 23989713]

8. Correll RN, Eder P, Burr AR, Despa S, Davis J, Bers DM, Molkentin JD. Overexpression of the Na $+/ \mathrm{K}+$ ATPase alpha2 but not alpha1 isoform attenuates pathological cardiac hypertrophy and remodeling. Circulation research. 2014; 114:249-56. [PubMed: 24218169]

9. Shan J, Xie W, Betzenhauser M, Reiken S, Chen BX, Wronska A, Marks AR. Calcium leak through ryanodine receptors leads to atrial fibrillation in 3 mouse models of catecholaminergic polymorphic ventricular tachycardia. Circulation research. 2012; 111:708-17. [PubMed: 22828895]

10. Tang Y, Tian X, Wang R, Fill M, Chen SR. Abnormal termination of Ca2+ release is a common defect of RyR2 mutations associated with cardiomyopathies. Circulation research. 2012; 110:96877. [PubMed: 22374134]

11. Respress JL, van Oort RJ, Li N, Rolim N, Dixit SS, deAlmeida A, Voigt N, Lawrence WS, Skapura DG, Skardal K, Wisloff U, Wieland T, Ai X, Pogwizd SM, Dobrev D, Wehrens XH. Role of RyR2 phosphorylation at S2814 during heart failure progression. Circulation research. 2012; 110:1474-83. [PubMed: 22511749]

12. Dobrev D, Wehrens XH. Role of RyR2 phosphorylation in heart failure and arrhythmias: Controversies around ryanodine receptor phosphorylation in cardiac disease. Circulation research. 2014; 114:1311-9. discussion 1319. [PubMed: 24723656]

13. Houser SR. Role of RyR2 phosphorylation in heart failure and arrhythmias: protein kinase Amediated hyperphosphorylation of the ryanodine receptor at serine 2808 does not alter cardiac contractility or cause heart failure and arrhythmias. Circulation research. 2014; 114:1320-7. discussion 1327. [PubMed: 24723657]

14. Frangogiannis NG, Smith CW, Entman ML. The inflammatory response in myocardial infarction. Cardiovascular research. 2002; 53:31-47. [PubMed: 11744011]

15. Chen Y, Corriden R, Inoue Y, Yip L, Hashiguchi N, Zinkernagel A, Nizet V, Insel PA, Junger WG. ATP release guides neutrophil chemotaxis via P2Y2 and A3 receptors. Science. 2006; 314:1792-5. [PubMed: 17170310]

16. Bonner F, Borg N, Jacoby C, Temme S, Ding Z, Flogel U, Schrader J. Ecto-5'-nucleotidase on immune cells protects from adverse cardiac remodeling. Circulation research. 2013; 113:301-12. [PubMed: 23720442]

17. Creemers EE, Cleutjens JP, Smits JF, Daemen MJ. Matrix metalloproteinase inhibition after myocardial infarction: a new approach to prevent heart failure? Circulation research. 2001; 89:201-10. [PubMed: 11485970]

18. Iyer RP, de Castro Bras LE, Jin YF, Lindsey ML. Translating Koch's postulates to identify matrix metalloproteinase roles in postmyocardial infarction remodeling: cardiac metalloproteinase actions (CarMA) postulates. Circulation research. 2014; 114:860-71. [PubMed: 24577966]

19. Spinale FG, Janicki JS, Zile MR. Membrane-associated matrix proteolysis and heart failure. Circulation research. 2013; 112:195-208. [PubMed: 23287455]

20. Zavadzkas JA, Stroud RE, Bouges S, Mukherjee R, Jones JR, Patel RK, McDermott PJ, Spinale FG. Targeted overexpression of tissue inhibitor of matrix metalloproteinase-4 modifies postmyocardial infarction remodeling in mice. Circulation research. 2014; 114:1435-45. [PubMed: 24637197]

21. Aurora AB, Porrello ER, Tan W, Mahmoud AI, Hill JA, Bassel-Duby R, Sadek HA, Olson EN. Macrophages are required for neonatal heart regeneration. The Journal of clinical investigation. 2014; 124:1382-92. [PubMed: 24569380]

22. Ismahil MA, Hamid T, Bansal SS, Patel B, Kingery JR, Prabhu SD. Remodeling of the mononuclear phagocyte network underlies chronic inflammation and disease progression in heart failure: critical importance of the cardiosplenic axis. Circulation research. 2014; 114:266-82. [PubMed: 24186967]

23. Heidt T, Courties G, Dutta P, Sager HB, Sebas M, Iwamoto Y, Sun Y, Da Silva N, Panizzi P, van der Laan AM, Swirski FK, Weissleder R, Nahrendorf M. Differential contribution of monocytes to heart macrophages in steady-state and after myocardial infarction. Circulation research. 2014; 115:284-95. [PubMed: 24786973] 
24. Hilgendorf I, Gerhardt LM, Tan TC, Winter C, Holderried TA, Chousterman BG, Iwamoto Y, Liao R, Zirlik A, Scherer-Crosbie M, Hedrick CC, Libby P, Nahrendorf M, Weissleder R, Swirski FK. Ly-6Chigh monocytes depend on $\mathrm{Nr} 4 \mathrm{a} 1$ to balance both inflammatory and reparative phases in the infarcted myocardium. Circulation research. 2014; 114:1611-22. [PubMed: 24625784]

25. Weirather J, Hofmann UD, Beyersdorf N, Ramos GC, Vogel B, Frey A, Ertl G, Kerkau T, Frantz S. Foxp3+ CD4+ T cells improve healing after myocardial infarction by modulating monocyte/ macrophage differentiation. Circulation research. 2014; 115:55-67. [PubMed: 24786398]

26. Hullmann JE, Grisanti LA, Makarewich CA, Gao E, Gold JI, Chuprun JK, Tilley DG, Houser SR, Koch WJ. GRK5-mediated exacerbation of pathological cardiac hypertrophy involves facilitation of nuclear NFAT activity. Circulation research. 2014; 115:976-85. [PubMed: 25332207]

27. Matsushima S, Kuroda J, Ago T, Zhai P, Park JY, Xie LH, Tian B, Sadoshima J. Increased oxidative stress in the nucleus caused by Nox4 mediates oxidation of HDAC4 and cardiac hypertrophy. Circulation research. 2013; 112:651-63. [PubMed: 23271793]

28. Kong Y, Tannous P, Lu G, Berenji K, Rothermel BA, Olson EN, Hill JA. Suppression of class I and II histone deacetylases blunts pressure-overload cardiac hypertrophy. Circulation. 2006; 113:2579-88. [PubMed: 16735673]

29. Toko H, Konstandin MH, Doroudgar S, Ormachea L, Joyo E, Joyo AY, Din S, Gude NA, Collins B, Volkers M, Thuerauf DJ, Glembotski CC, Chen CH, Lu KP, Muller OJ, Uchida T, Sussman MA. Regulation of cardiac hypertrophic signaling by prolyl isomerase Pin1. Circulation research. 2013; 112:1244-52. [PubMed: 23487407]

30. Hariharan N, Sussman MA. Pin1: a molecular orchestrator in the heart. Trends in cardiovascular medicine. 2014; 24:256-62. [PubMed: 25070718]

31. Wever-Pinzon O, Drakos SG, Kfoury AG, Nativi JN, Gilbert EM, Everitt M, Alharethi R, Brunisholz K, Bader FM, Li DY, Selzman CH, Stehlik J. Morbidity and mortality in heart transplant candidates supported with mechanical circulatory support: is reappraisal of the current United network for organ sharing thoracic organ allocation policy justified? Circulation. 2013; 127:452-62. [PubMed: 23271796]

32. Maybaum S, Mancini D, Xydas S, Starling RC, Aaronson K, Pagani FD, Miller LW, Margulies K, McRee S, Frazier OH, Torre-Amione G, Group LW. Cardiac improvement during mechanical circulatory support: a prospective multicenter study of the LVAD Working Group. Circulation. 2007; 115:2497-505. [PubMed: 17485581]

33. Birks EJ. Molecular changes after left ventricular assist device support for heart failure. Circulation research. 2013; 113:777-91. [PubMed: 23989719]

34. Gama-Carvalho M, Andrade J, Bras-Rosario L. Regulation of Cardiac Cell Fate by microRNAs: Implications for Heart Regeneration. Cells. 2014; 3:996-1026. [PubMed: 25358052]

35. Luo X, Yang B, Nattel S. MicroRNAs and atrial fibrillation: mechanisms and translational potential. Nature reviews Cardiology. 2014

36. Thum T, Galuppo P, Wolf C, Fiedler J, Kneitz S, van Laake LW, Doevendans PA, Mummery CL, Borlak J, Haverich A, Gross C, Engelhardt S, Ertl G, Bauersachs J. MicroRNAs in the human heart: a clue to fetal gene reprogramming in heart failure. Circulation. 2007; 116:258-67. [PubMed: 17606841]

37. Huang ZP, Chen J, Seok HY, Zhang Z, Kataoka M, Hu X, Wang DZ. MicroRNA-22 regulates cardiac hypertrophy and remodeling in response to stress. Circulation research. 2013; 112:123443. [PubMed: 23524588]

38. Li RC, Tao J, Guo YB, Wu HD, Liu RF, Bai Y, Lv ZZ, Luo GZ, Li LL, Wang M, Yang HQ, Gao W, Han QD, Zhang YY, Wang XJ, Xu M, Wang SQ. In vivo suppression of microRNA-24 prevents the transition toward decompensated hypertrophy in aortic-constricted mice. Circulation research. 2013; 112:601-5. [PubMed: 23307820]

39. Wahlquist C, Jeong D, Rojas-Munoz A, Kho C, Lee A, Mitsuyama S, van Mil A, Park WJ, Sluijter JP, Doevendans PA, Hajjar RJ, Mercola M. Inhibition of miR-25 improves cardiac contractility in the failing heart. Nature. 2014; 508:531-5. [PubMed: 24670661]

40. Bush EW, van Rooij E. miR-25 in heart failure. Circulation research. 2014; 115:610-2. [PubMed: 25214573]

Circ Res. Author manuscript; available in PMC 2016 September 11. 
41. Matsumoto S, Sakata Y, Suna S, Nakatani D, Usami M, Hara M, Kitamura T, Hamasaki T, Nanto S, Kawahara Y, Komuro I. Circulating p53-responsive microRNAs are predictive indicators of heart failure after acute myocardial infarction. Circulation research. 2013; 113:322-6. [PubMed: 23743335]

42. Kuwabara Y, Ono K, Horie T, Nishi H, Nagao K, Kinoshita M, Watanabe S, Baba O, Kojima Y, Shizuta S, Imai M, Tamura T, Kita T, Kimura T. Increased microRNA-1 and microRNA-133a levels in serum of patients with cardiovascular disease indicate myocardial damage. Circulation Cardiovascular genetics. 2011; 4:446-54. [PubMed: 21642241]

43. Xiao J, Shen B, Li J, Lv D, Zhao Y, Wang F, Xu J. Serum microRNA-499 and microRNA-208a as biomarkers of acute myocardial infarction. International journal of clinical and experimental medicine. 2014; 7:136-41. [PubMed: 24482699]

44. Matkovich SJ, Hu Y, Dorn GW 2nd. Regulation of cardiac microRNAs by cardiac microRNAs. Circulation research. 2013; 113:62-71. [PubMed: 23625950]

45. Gwathmey JK, Yerevanian A, Hajjar RJ. Targeting sarcoplasmic reticulum calcium ATPase by gene therapy. Human gene therapy. 2013; 24:937-47. [PubMed: 24164241]

46. Chaudhri BB, del Monte F, Harding SE, Hajjar RJ. Gene transfer in cardiac myocytes. The Surgical clinics of North America. 2004; 84:141-59. ix-x. [PubMed: 15053187]

47. del Monte F, Williams E, Lebeche D, Schmidt U, Rosenzweig A, Gwathmey JK, Lewandowski ED, Hajjar RJ. Improvement in survival and cardiac metabolism after gene transfer of sarcoplasmic reticulum $\mathrm{Ca}(2+)$-ATPase in a rat model of heart failure. Circulation. 2001; 104:1424-9. [PubMed: 11560860]

48. Byrne MJ, Power JM, Preovolos A, Mariani JA, Hajjar RJ, Kaye DM. Recirculating cardiac delivery of AAV2/1SERCA2a improves myocardial function in an experimental model of heart failure in large animals. Gene therapy. 2008; 15:1550-7. [PubMed: 18650850]

49. Kawase Y, Ly HQ, Prunier F, Lebeche D, Shi Y, Jin H, Hadri L, Yoneyama R, Hoshino K, Takewa Y, Sakata S, Peluso R, Zsebo K, Gwathmey JK, Tardif JC, Tanguay JF, Hajjar RJ. Reversal of cardiac dysfunction after long-term expression of SERCA2a by gene transfer in a preclinical model of heart failure. Journal of the American College of Cardiology. 2008; 51:1112-9. [PubMed: 18342232]

50. Jaski BE, Jessup ML, Mancini DM, Cappola TP, Pauly DF, Greenberg B, Borow K, Dittrich H, Zsebo KM, Hajjar RJ. Calcium Up-Regulation by Percutaneous Administration of Gene Therapy In Cardiac Disease Trial I. Calcium upregulation by percutaneous administration of gene therapy in cardiac disease (CUPID Trial), a first-in-human phase 1/2 clinical trial. Journal of cardiac failure. 2009; 15:171-81. [PubMed: 19327618]

51. Jessup M, Greenberg B, Mancini D, Cappola T, Pauly DF, Jaski B, Yaroshinsky A, Zsebo KM, Dittrich H, Hajjar RJ. Calcium Upregulation by Percutaneous Administration of Gene Therapy in Cardiac Disease I. Calcium Upregulation by Percutaneous Administration of Gene Therapy in Cardiac Disease (CUPID): a phase 2 trial of intracoronary gene therapy of sarcoplasmic reticulum Ca2+-ATPase in patients with advanced heart failure. Circulation. 2011; 124:304-13. [PubMed: 21709064]

52. Zsebo K, Yaroshinsky A, Rudy JJ, Wagner K, Greenberg B, Jessup M, Hajjar RJ. Long-term effects of AAV1/SERCA2a gene transfer in patients with severe heart failure: analysis of recurrent cardiovascular events and mortality. Circulation research. 2014; 114:101-8. [PubMed: 24065463]

53. Furtado MB, Costa MW, Pranoto EA, Salimova E, Pinto AR, Lam NT, Park A, Snider P, Chandran A, Harvey RP, Boyd R, Conway SJ, Pearson J, Kaye DM, Rosenthal NA. Cardiogenic genes expressed in cardiac fibroblasts contribute to heart development and repair. Circulation research. 2014; 114:1422-34. [PubMed: 24650916]

54. Chen J, Huang ZP, Seok HY, Ding J, Kataoka M, Zhang Z, Hu X, Wang G, Lin Z, Wang S, Pu WT, Liao R, Wang DZ. mir-17-92 cluster is required for and sufficient to induce cardiomyocyte proliferation in postnatal and adult hearts. Circulation research. 2013; 112:1557-66. [PubMed: 23575307]

55. Yaniz-Galende E, Chen J, Chemaly E, Liang L, Hulot JS, McCollum L, Arias T, Fuster V, Zsebo KM, Hajjar RJ. Stem cell factor gene transfer promotes cardiac repair after myocardial infarction via in situ recruitment and expansion of c-kit+ cells. Circulation research. 2012; 111:1434-45. [PubMed: 22931954] 
56. Lin Z, von Gise A, Zhou P, Gu F, Ma Q, Jiang J, Yau AL, Buck JN, Gouin KA, van Gorp PR, Zhou B, Chen J, Seidman JG, Wang DZ, Pu WT. Cardiac-specific YAP activation improves cardiac function and survival in an experimental murine MI model. Circulation research. 2014; 115:354-63. [PubMed: 24833660]

57. Molkentin JD. Letter by Molkentin regarding article, "The absence of evidence is not evidence of absence: the pitfalls of Cre Knock-Ins in the c-Kit Locus". Circulation research. 2014; 115:e21-3. [PubMed: 25258403]

58. Molkentin JD, Houser SR. Are resident c-Kit+ cardiac stem cells really all that are needed to mend a broken heart? Circulation research. 2013; 113:1037-9. [PubMed: 24115067]

59. Molkentin JD, Houser SR. Response to Torella et al. Circulation research. 2014; 114:e27. [PubMed: 24526680]

60. van Berlo JH, Kanisicak O, Maillet M, Vagnozzi RJ, Karch J, Lin SC, Middleton RC, Marban E, Molkentin JD. c-kit+ cells minimally contribute cardiomyocytes to the heart. Nature. 2014; 509:337-41. [PubMed: 24805242]

61. Ellison GM, Vicinanza C, Smith AJ, Aquila I, Leone A, Waring CD, Henning BJ, Stirparo GG, Papait R, Scarfo M, Agosti V, Viglietto G, Condorelli G, Indolfi C, Ottolenghi S, Torella D, Nadal-Ginard B. Adult c-kit(pos) cardiac stem cells are necessary and sufficient for functional cardiac regeneration and repair. Cell. 2013; 154:827-42. [PubMed: 23953114]

62. Karantalis V, Hare JM. Use of Mesenchymal Stem Cells for Therapy of Cardiac Disease. Circulation research. 2015; 116:1413-1430. [PubMed: 25858066]

63. Henry TD, Traverse JH, Hammon BL, East CA, Bruckner B, Remmers AE, Recker D, Bull DA, Patel AN. Safety and efficacy of ixmyelocel-T: an expanded, autologous multi-cellular therapy, in dilated cardiomyopathy. Circulation research. 2014; 115:730-7. [PubMed: 25142002]

64. Ishigami S, Ohtsuki S, Tarui S, Ousaka D, Eitoku T, Kondo M, Okuyama M, Kobayashi J, Baba K, Arai S, Kawabata T, Yoshizumi K, Tateishi A, Kuroko Y, Iwasaki T, Sato S, Kasahara S, Sano S, Oh H. Intracoronary autologous cardiac progenitor cell transfer in patients with hypoplastic left heart syndrome: the TICAP prospective phase 1 controlled trial. Circulation research. 2015; 116:653-64. [PubMed: 25403163]

65. Jimenez-Quevedo P, Gonzalez-Ferrer JJ, Sabate M, Garcia-Moll X, Delgado-Bolton R, Llorente L, Bernardo E, Ortega-Pozzi A, Hernandez-Antolin R, Alfonso F, Gonzalo N, Escaned J, Banuelos C, Regueiro A, Marin P, Fernandez-Ortiz A, Neves BD, Del Trigo M, Fernandez C, Tejerina T, Redondo S, Garcia E, Macaya C. Selected CD133(+) progenitor cells to promote angiogenesis in patients with refractory angina: final results of the PROGENITOR randomized trial. Circulation research. 2014; 115:950-60. [PubMed: 25231095]

66. Karantalis V, DiFede DL, Gerstenblith G, Pham S, Symes J, Zambrano JP, Fishman J, Pattany P, McNiece I, Conte J, Schulman S, Wu K, Shah A, Breton E, Davis-Sproul J, Schwarz R, Feigenbaum G, Mushtaq M, Suncion VY, Lardo AC, Borrello I, Mendizabal A, Karas TZ, Byrnes J, Lowery M, Heldman AW, Hare JM. Autologous mesenchymal stem cells produce concordant improvements in regional function, tissue perfusion, and fibrotic burden when administered to patients undergoing coronary artery bypass grafting: The Prospective Randomized Study of Mesenchymal Stem Cell Therapy in Patients Undergoing Cardiac Surgery (PROMETHEUS) trial. Circulation research. 2014; 114:1302-10. [PubMed: 24565698]

67. Suncion VY, Ghersin E, Fishman JE, Zambrano JP, Karantalis V, Mandel N, Nelson KH, Gerstenblith G, DiFede Velazquez DL, Breton E, Sitammagari K, Schulman IH, Taldone SN, Williams AR, Sanina C, Johnston PV, Brinker J, Altman P, Mushtaq M, Trachtenberg B, Mendizabal AM, Tracy M, Da Silva J, McNiece IK, Lardo AC, George RT, Hare JM, Heldman AW. Does transendocardial injection of mesenchymal stem cells improve myocardial function locally or globally?: An analysis from the Percutaneous Stem Cell Injection Delivery Effects on Neomyogenesis (POSEIDON) randomized trial. Circulation research. 2014; 114:1292-301. [PubMed: 24449819]

68. Lauden L, Boukouaci W, Borlado LR, Lopez IP, Sepulveda P, Tamouza R, Charron D, Al-Daccak R. Allogenicity of human cardiac stem/progenitor cells orchestrated by programmed death ligand 1. Circulation research. 2013; 112:451-64. [PubMed: 23243206]

69. Houtgraaf JH, de Jong R, Kazemi K, de Groot D, van der Spoel TI, Arslan F, Hoefer I, Pasterkamp G, Itescu S, Zijlstra F, Geleijnse ML, Serruys PW, Duckers HJ. Intracoronary infusion of 
allogeneic mesenchymal precursor cells directly after experimental acute myocardial infarction reduces infarct size, abrogates adverse remodeling, and improves cardiac function. Circulation research. 2013; 113:153-66. [PubMed: 23658436] 